

\title{
EVALUASI KELAYAKAN BISNIS STEAM MOBIL “TOP CLEAN” TANGERANG SELATAN DITINJAU DARI ASPEK OPERASIONAL
}

\author{
Syamruddin \\ Fakultas Ekonomi, Universitas Pamulang \\ doseno1343@unpam.ac.id
}

\begin{abstract}
Abstrak
Saat ini, di setiap sisi jalan sering kita jumpai layanan cuci mobil. Hal tersebut disebabkan karena bagi kebanyakan masyarakat kota, jasa cuci mobil merupakan suatu kebutuhan dan sarana untuk mencuci kendaraan mereka yang sangat praktis, di sela-sela kesibukan serta rutinitas keja sehari-hari. Jasa cuci mobil pun terus berkembang dan menjadi suatu peluang bisnis yang cukup menjanjikan sehingga perlu dikelola secara profesional. Seiring dengan semakin berkembangnya bisnis jasa cuci mobil ini, maka sudah sewajarnya pula dilakukan suatu evaluasi mengenai layak tidaknya bisnis tersebut. Pada umumnya Evaluasi Kelayakan Bisnis sudah banyak dikenal masyarakat. Terutama masyarakat yang bergerak dalam dunia bisnis. Oleh karena itu tujuan penelitian ini untuk mengetahui tentang evaluasi dan gambaran kelayakan bisnis Steam Mobil "Top Clean" yang berlokasi di Kota Tangerang Selatan dari aspek operasional. Adapun Evaluasi Kelayakan Bisnis diperlukan untuk melihat suatu gambaran mengenai layak tidak layaknya suatu bisnis yang akan dijalankan. Selanjutnya metode penelitian yang digunakan adalah metode penelitian deskriptif kualitatif. Metode pengumpulan data dilakukan dengan melakukan wawancara dan observasi. Teknik sampel yang digunakan adalah nonprobability. Teknik analisis data yang digunakan adalah dengan Matriks SWOT dengan cara analisis matriks IE, IFAS, dan EFAS. Berdasarkan hasil penelitian, maka diperoleh gambaran bahwa kelayakan bisnis Steam Mobil "Top Clean" dinyatakan layak. Hasil dari dari faktor internal dan eksternal dalam operasional berada di tingkat yang tinggi. Aspek operasional ini memperoleh hitungan Bobot Matriks SWOT sebesar 3,27 untuk faktor internal dan 3,O7 untuk faktor eksternal. Dengan demikian sesuai hasil tersebut berarti Steam Mobil "Top Clean" ini layak untuk terus dijalankan.
\end{abstract}

Kata Kunci : Studi Kelayakan Bisnis, SWOT, Manajemen Strategi

\begin{abstract}
At present, on each side of the road we often encounter car wash services. That is because for most urban people, car washing services are a necessity and a means to wash their vehicles which is very practical, in the midst of busyness and daily routine. Car wash services continue to grow and become a promising business opportunity that needs to be managed professionally. As the car wash service business grows, it is also natural to conduct an evaluation of the
\end{abstract}


suitability of the business. In general, Business Feasibility Evaluation is widely known by the public. Especially people who are engaged in the business world. Therefore the purpose of this research is to find out about the evaluation and feasibility of the "Top Clean" Steam Car business located in South Tangerang City from an operational aspect. The Business Feasibility Evaluation is needed to see a picture of the suitability of a business to be run. Furthermore, the research method used is descriptive qualitative research method. Data collection method is done by conducting interviews and observations. The sample technique used is nonprobability. Data analysis technique used is the SWOT matrix by means of IE, IFAS, and EFAS matrix analysis. Based on the research results, it is obtained that the feasibility of the "Top Clean" Steam Car business is feasible. The results of internal and external factors in operations are at a high level. This operational aspect obtains a SWOT Matrix Weight calculation of 3,27 for internal factors and 3,07 for external factors. Thus according to these results means the Steam Car "Top Clean" is worthy to continue running.

Keywords : Business Feasibility Study, SWOT, Strategy Management

\section{PENDAHULUAN}

Belakangan ini bisnis pencucian mobil dan motor atau yang lebih familiar dengan sebutan steam mobil dan motor semakin berkembang. Bahkan, banyak sekali pelaku usaha yang berani terjun ke bisnis ini sehingga di mana-mana tampak berbagai pelaku usaha di berbagai tempat yang memberikan penawaran untuk membuat kendaraan seperti baru kembali. Ibarat bak jamur di musim hujan, pelaku usaha steam mobil dan motor pun tumbuh di mana-mana.

Tak hanya sekadar sebagai tempat untuk pencucian mobil dan motor, usaha ini pun berkembang menjadi alternatif bisnis, karena di dalamnya tidak hanya menawarkan pencucian mobil dan motor, namun juga sebagai tempat perawatan kendaraan hingga tempat kuliner seperti adanya restoran dan café.

Salah satu contoh tempat bisnis cuci mobil yang terus berkembang adalah Steam
Mobil “Top Clean”. Jasa cuci mobil yang terletak di jalan utama lintas provinsi yakni di Jalan Setiabudi, Tangerang Selatan ini setiap harinya selalu ramai dikunjungi pemilik mobil. Sejak berdirinya pada Juli 2015, steam mobil ini tidak pernah sepi. Padahal tidak jauh dari lokasi tersebut, banyak juga jasa pencucian mobil. Namun tampak sepi dari pengguna jasa cuci kendaraan, bahkan di antaranya sudah ada pula yang tutup. Omset yang terus menurun, membuat jasa pencucian mobil lainnya tak mampu bersaing dengan Steam Mobil “Top Clean”.

Di awal berdirinya kurang lebih lima tahun yang lalu, pemilik Steam Mobil “Top Clean" yang berasal dari Purbalingga ini, menginvestasikan modalnya sekitar Rp. 1,5 miliar. Investasi itu berupa sewa tempat, renovasi, biaya awal operasional, dan lainlain. Hal itu sebagaimana tergambar pada tabel di bawah ini. 


\begin{tabular}{|c|c|c|}
\hline \multicolumn{3}{|c|}{ Tabel 1.1. Investasi Bisnis } \\
\hline No. & Uraian & Jumlah \\
\hline 1. & $\begin{array}{l}\text { Sewa Tempat selama } 10 \\
\text { Tahun }\end{array}$ & Rp. 900.000.000,- \\
\hline 2. & $\begin{array}{l}\text { Bangunan }+ \text { Renovasi } \\
\text { Tempat }\end{array}$ & Rp. 350.000.000,- \\
\hline 3. & Biaya Operasional Awal & Rp. $150.000 .000,-$ \\
\hline 4. & Pembelian Peralatan & Rp. $\quad 75.000 .000,-$ \\
\hline 5. & Lain-lain & Rp. $\quad 25.000 .000,-$ \\
\hline & Jumlah & Rp. 1.500.000.000,- \\
\hline
\end{tabular}

Banyaknya pengunjung pada setiap harinya yang datang mencucikan kendaraannya ke Steam Mobil "TOP CLEAN”, dikarenakan pelayanan yang handal dan prima dari para tenaga pencucinya. Selain itu fasilitas tempat pencucian mobil yang memadai dengan jumlah yang tergolong cukup sehingga pengguna jasa pencucian mobil ini tidak perlu harus antre menunggu lama. Jumlah karyawan dan fasilitas tempat pencucian yang ada sebagaimana diuraikan pada tabel di bawah ini.

\begin{tabular}{|c|l|c|}
\hline \multicolumn{3}{|c|}{ Tabel 1.2. Karyawan dan Fasilitas } \\
\hline No. & \multicolumn{1}{|c|}{ Uraian } & Jumlah \\
\hline 1. & Manajer & 1 orang \\
\hline 2. & Tenaga Pencuci & 14 orang \\
\hline 3. & Fasilitas Pencucian & 12 tempat \\
\hline
\end{tabular}

Sumber : Manajemen Steam Mobil "TOP CLEAN", 2019

Selain fasilitas tempat pencucian dan tenaga pencucian yang mumpuni, didukung pelayanan yang handal, paket harga yang ditawarkan oleh manajemen Steam Mobil "TOP CLEAN" pun terbilang cukup murah. Kendati harga paketnya yang murah, bukan berarti pelayanan yang diberikan tidak maksimal sehingga hasil yang diperoleh tidak memuaskan. Seperti kurang bersihnya mobil yang dicuci.

Manajemen jasa pencucian mobil ini tetap memberikan pelayanan yang maksimal dengan hasil yang baik sehingga pengendara merasa puas. Harga yang murah tidak membuat hasil yang diperoleh konsumen kurang memuaskan. Tapi sebaliknya dengan harga yang murah, hasil yang didapatkan juga sangat memuaskan.

Adapun paket harga yang ditawarkan manajemen Steam Mobil "TOP CLEAN" bervariasi dan tergolong cukup murah dibanding jasa cuci mobil yang lainnya yaitu antara Rp. 15 ribu sampai dengan Rp. 35 ribu. Selain melayani pencucian mobil, steam ini juga melayani pencucian sepeda motor. Hal itu sebagaimana tampak pada tabel di bawah ini.

\begin{tabular}{|c|l|c|}
\hline \multicolumn{3}{|c}{ Tabel 1.3. Paket Harga Yang Ditawarkan } \\
\hline No. & \multicolumn{1}{|c|}{ Uraian } & Harga \\
\hline 1. & Cuci Body & Rp. 15.000,- \\
\hline 2. & Cuci Body + Poles Ban & Rp. 20.000,- \\
\hline 3. & Cuci Body + Vacum & Rp. 22.000,- \\
\hline 4. & Cuci Body + Vacum + Semir & Rp. 25.000,- \\
\hline 5. & $\begin{array}{l}\text { Cuci Body + Vacum + Semir } \\
\text { + Kolong + Mesin }\end{array}$ & Rp. 35.000,- \\
\hline 6. & $\begin{array}{l}\text { Cuci Motor Kecil (Mio, Bebek, } \\
\text { Vario, dll) }\end{array}$ & Rp. 12.000,- \\
\hline 7. & $\begin{array}{l}\text { Cuci Motor Besar (King, } \\
\text { Vixion, Ninja, dll) }\end{array}$ & Rp. 15.000,- \\
\hline
\end{tabular}

Sumber : Manajemen Steam Mobil “TOP CLEAN”, 2019

Seiring dengan perjalanannya, Steam Mobil “TOP CLEAN” pun terus berkembang. Pada tahun pertama berdirinya, keuntungan yang diperoleh rata-rata hanya sekitar Rp. 20 juta per bulan. Namun dari tahun ke tahun keuntungan semakin terus meningkat. Sementara itu biaya bahan pencucian mobil dan peralatan lainnya walaupun mengalami peningkatan, namun peningkatannya tidak signifikan. Begitu pula dengan biaya pemeliharaan mesin dan biaya lainnya walaupun mengalami peningkatan, namun tidak begitu signifikan peningkatannya. 
Secara umum ikhtisar keuangan tergambar pada tabel di bawah ini.

Tabel 1.4. Ikhtisar Keuangan

\begin{tabular}{|c|c|c|c|c|c|}
\hline No. & Uraian & Tahun 2015 & Tahun 2016 & Tahun 2017 & Tahun 2018 \\
\hline 1. & Pendapatan & Rp. 120.350 .000$, & Rp. 322.367 .000 - & Rp. $350.685 .000,-$ & Rp. $378.320 .000,-$ \\
\hline 2. & $\frac{\text { Biaya }}{\text { Operasional }}$ & Rp. 90.000 .000$, & Rp. 175.000 .000 - & Rp. 185.000 .000 - & Rp. 195.000.000, \\
\hline 3. & $\begin{array}{l}\text { Pembelian } \\
\text { Bahan dan } \\
\text { Peralatan }\end{array}$ & Rp. 5.000.000,- & Rp.$\underline{6.000 .000,-}$ & Rp. $\underline{8.000 .000,-}$ & Rp. $9.500 .000,-$ \\
\hline 4. & $\begin{array}{l}\text { Biava } \\
\text { Pemeliharaan }\end{array}$ & Rp. 1.000.000,- & Rp. 2.000.000,- & Rp. 3.500.000,- & Rp. 5.500.000,- \\
\hline
\end{tabular}

Sumber : Manajemen Steam Mobil “TOP CLEAN”, 2019

Tabel 1.4. di atas menunjukkan bahwa

biaya operasional terus meningkat. Kendati pendapatan juga mengalami peningkatan setiap tahunnya, namun dari sisi investasi yang telah ditanamkan belum bisa dikatakan sudah memuaskan. Sebab investasi bisnis untuk 10 tahun tersebut apabila dilihat dari keuntungan selama empat tahun, seyogianya target keuntungan bersih pada setiap tahunnya harus lebih dari Rp. 175 juta. Karena apabila dari jumlah tersebut bisa diperoleh, maka baru bisa mengembalikan modal yang sudah diinvestasikan ditambah sedikit laba yang diperoleh. Sebab, sebagai pebisnis sudah barang tentu pasti mengharapkan laba yang lebih besar, tidak hanya bisa untuk mengembalikan modal, namun juga mendapatkan keuntungan setelah dikurangi biaya-biaya dan investasi yang ditanamkan.

Salah satu upaya yang dilakukan untuk meningkatkan pendapatan Steam Mobil "TOP CLEAN" adalah dengan memperbaiki dan meningkatkan aspek operasional. Berbagai cara dapat dilakukan, misalnya dengan peningkatan pelayanan yang diikuti dengan kenaikan harga dan promosi lainnya. Sebab ketika harga dinaikkan, maka harus diikuti dengan pelayanan yang lebih baik. Dengan demikian para pelanggan Steam Mobil "TOP CLEAN" akan tetap loyal untuk menggunakan jasa usaha pencucian mobil ini.

Berdasarkan uraian di atas, mengenai kendala dalam operasional Steam Mobil “TOP CLEAN", maka penulis tertarik untuk melakukan penelitian dengan judul: Evaluasi Kelayakan Bisnis Steam Mobil "Top Clean" Kota Tangerang Selatan Ditinjau Dari Aspek Operasional.

Sesuai dengan latar belakang di atas, maka penulis merumuskan masalah sebagai berikut :

1. Mengidentifikasi hal-hal apa saja yang telah dilakukan Steam Mobil "TOP CLEAN" ditinjau dari aspek operasional.

2. Mengevaluasi kelayakan usaha Steam Mobil “TOP CLEAN" dari aspek operasional.

3. Langkah apa saja yang dilakukan untuk membuat usaha Steam Mobil “TOP CLEAN" layak untuk dilanjutkan dari aspek operasional.

\section{METODE}

Adapun metode penelitian yang digunakan adalah metode penelitian deskriptif kualitatif. Metode pengumpulan data dilakukan dengan melakukan wawancara dan observasi. Teknik sampel yang digunakan adalah nonprobability. 
Teknik analisis data yang digunakan adalah Analisis SWOT dengan cara Analisis Matriks IE, IFAS, dan EFAS.

\section{HASIL dan PEMBAHASAN}

SWOT adalah metode perencanaan strategis yang digunakan untuk mengevaluasi kekuatan (strenghts), kelemahan (weaknesses), peluang (opportunities), dan ancaman (threats) dalam suatu proyek atau suatu spekulasi bisnis. Keempat faktor tersebutlah yang membentuk akronim SWOT (strenghts, weaknesses, opportunities, threats). SWOT akan lebih baik apabila dibahas dengan menggunakan tabel yang dibuat dalam kertas besar. Dengan demikian dapat dianalisis dengan baik hubungan dari setiap aspek.

Proses ini melibatkan penentuan tujuan yang spesifik dari spekulasi bisnis atau proyek dan mengidentifikasi faktor internal dan eksternal yang mendukung dan yang tidak dalam mencapai tujuan tersebut. Analisis SWOT dapat diterapkan dengan cara menganalisis dan memilah berbagai hal yang mempengaruhi keempat faktornya, yang kemudian menerapkannya dalam gambar Matriks SWOT.

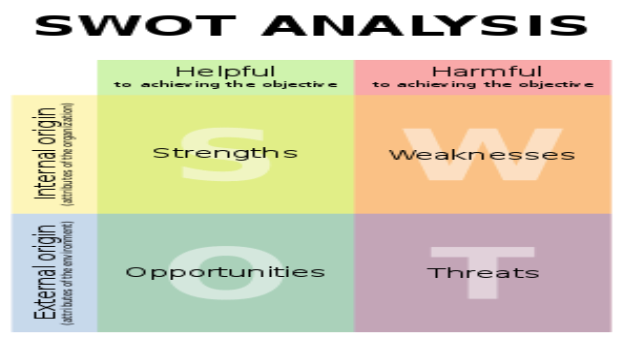

Gambar 1. Diagram Ilustrasi Analisis SWOT
Dalam aplikasinya, Analisis Matriks SWOT mencerminkan bagaimana kekuatan (strengths) mampu mengambil keuntungan (advantage) dari peluang (opportunities) yang ada. Kemudian bagaimana cara mengatasi kelemahan (weaknesses) yang mencegah keuntungan (advantage) dari peluang (opportunities) yang ada.

Selanjutnya, bagaimana kekuatan (strengths) mampu menghadapi ancaman (threats) yang ada. Terakhir, adalah bagaimana cara mengatasi kelemahan (weaknesses) yang mampu membuat ancaman (threats) menjadi nyata atau menciptakan sebuah ancaman baru.

Sebagaimana dikutip dari https:// id.wikipedia.org/wiki/Analisis_SWOT, per 27 Juli 2019, Teknik Analisis SWOT ini dibuat oleh Albert Humphrey, yang memimpin proyek riset di Universitas Stanford, Amerika Serikat pada dasawarsa 1960-an dan 1970-an. Dalam riset tersebut, dia menggunakan data dari perusahaanperusahaan Fortune 500. Sedangkan Fortune 500 adalah sebuah daftar tahunan yang disusun dan diterbitkan oleh Majalah Fortune yang memeringkatkan 500 perusahaan umum dan milik pemerintah teratas yang diperingkatkan berdasarkan pendapatan bruto mereka setelah penyesuaian dibuat oleh Fortune untuk menghindari dampak pajak eksis yang dikumpulkan perusahaan. Daftar ini mencakup perusahaan umum dan swasta 
yang pendapatannya dapat dilihat oleh public .

Semua organisasi memiliki kekuatan dan kelemahan dalam area fungsional bisnis yang tercermin dalam SWOT. Kekuatan dan kelemahan internal digabungkan dengan peluang atau ancaman dari eksternal dan pernyataan misi yang jelas, sehingga menjadi dasar penetapan tujuan dan strategi.

Penelitian menunjukkan bahwa kinerja perusahaan dapat ditentukan melalui kombinasi faktor internal dan eksternal. Kedua faktor tersebut harus dipertimbangkan dalam Analisis SWOT.

Adapun penjelasan secara garis besar mengenai SWOT adalah sebagai berikut :

1. Kekuatan (Strengths)

Kekuatan adalah sumber daya, keterampilan, kemampuan teknologi, dan keunggulan-keunggulan lain, yang berhubungan dengan para pesaing perusahaan dan kebutuhan-kebutuhan pasar yang dapat dilayani oleh perusahaan yang diharapkan dapat dilayani.

2. Kelemahan (Weaknesses)

Kelemahan adalah keterbatasan atau kekurangan dalam sumber daya, keterampilan, dan kemampuan yang secara efektif menghambat kinerja perusahaan.

3. Peluang (Opportunities)

Peluang adalah situasi penting yang menguntungkan dalam lingkungan perusahaan dan kecenderungan- kecenderungan penting yang merupakan salah satu sumber peluang, seperti perubahan teknologi dan meningkatnya hubungan antara perusahaan dengan pembeli atau pemasok, yang merupakan gambaran peluang bagi perusahaan.

4. Ancaman (Threats)

Ancaman adalah situasi penting yang tidak menguntungkan dalam lingkungan perusahaan. Ancaman pengganggu utama bagi posisi perusahaan sekarang atau yang diinginkan perusahaan pesaing. Perkembangan teknologi yang menyebabkan ancaman bagi perusahaan. Adanya perubahan peraturan pemerintah yang akan mengancam perkembangan organisasi.

Kemudian dilakukan Analisis Internal Factors Analysis Summary (IFAS) dan External Factors Analysis Summary (EFAS). IFAS merupakan kesimpulan analisis dari berbagai faktor internal yang mempengaruhi keberlangsungan perusahaan. EFAS merupakan kesimpulan analisis dari berbagai faktor eksternal yang mempengaruhi keberlangsungan perusahaan.

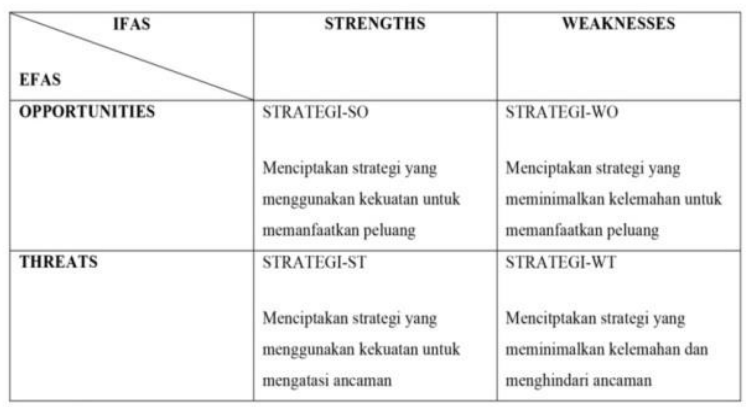

Gambar 1.2.Diagram Matriks SWOT 
Setelah itu dilakukan evaluasi terhadap faktor-faktor internal perusahaan berkaitan dengan dengan kekuatan dan kelemahan serta peluang dan ancaman. Yaitu dengan menggunakan Matriks Internal Factors Evaluation (IFE) dan Matriks External Factors Evaluation (EFE). Selanjutnya Analisis Matriks InternalExternal (IE), yang merupakan matriks portofolio yang memposisikan perusahaan dalam tampilan sembilan sel. Posisi suatu perusahaan dalam Matriks IE ditentukan dari Matriks EFE dan Matriks IFE. Hasil skor total dari Matriks IFE berada pada sumbu X dan hasil skor total dari Matriks EFE berada pada sumbu $Y$.

\section{Hasil}

\section{Faktor Lingkungan Internal dan Eksternal}

Berdasarkan hasil wawancara dengan Manajer Steam Mobil “TOP CLEAN”, yang memberikan pendapat dan penilaian terhadap faktor-faktor operasional di dalam organisasi, maka diperoleh data-data sebagai berikut :

\section{Faktor Kekuatan Internal}

1. Harga yang murah

Harga yang tergolong sangat murah dibanding dengan steam-steam yang lain di sekitar Pamulang dan Tangerang Selatan. Harga yang ditawarkan ini tidak semua ditawarkan oleh steam lain, dan justru berada di atas atau lebih mahal.
2. Lokasi strategis, dipinggir jalan raya utama

Lokasi yang sangat strategis, di mana persis berada di pinggir jalan raya utama yang merupakan jalan provinsi dan nasional. Sehingga mudah dijangkau dan tidak perlu harus mencari-cari lagi.

3. Memiliki 15 orang karyawan

Jumlah karyawan yang cukup banyak dan memadai membuat pelayanan semakin cepat. Tidak perlu menunggu. Begitu pelanggan sudah tiba di tempat steam dan ada tempat pencucian yang kosong maka langsung dilayani. Sehingga pelanggan merasa nyaman, apalagi bagi mereka yang ingin segera beraktivitas ke tempat lain.

\section{Faktor Kelemahan Internal}

1. Fasilitas yang dimiliki masih minim Minimnya fasilitas yang dimiliki membuat manajemen tidak bisa melakukan inovasi dan kreasi untuk menawarkan pelayanan yang lebih bagus lagi. Maksudnya, pelayanan yang lebih nyaman dan benarbenar memanjakan pelanggan belum bisa ditawarkan lebih maksimal.

2. Disiplin karyawan perlu ditingkatkan Masalah disiplin karyawan dirasakan masih peru ditingkatkan. Hal ini sejalan dengan semakin banyaknya pelanggan yang menggunakan jasa steam ini.

3. Promosi yang dilakukan masih kurang Manajemen merasakan promosi masih sangat kurang. Hal ini karena belum dikelolanya secara profesional pemasaran 
steam mobil ini. Selain itu karena kondisi pelanggan yang tidak pernah putus sehingga membuat manajemen merasa tidak perlu dilakukan promosi.

\section{Faktor Peluang Eksternal}

1. Jumlah pengguna mobil terus bertambah Kendaraan yang semakin hari semakin bertambah jumlahnya akan merupakan peluang bagi manajemen untuk terus berkembang. Dengan pertambahan kendaraan, maka membuka peluang untuk mengembangkan bisnisnya pada usaha steam mobil yang ter-integrated dengan usaha lain yang masih ada kaitannya dengan usaha steam mobil, seperti ganti olie mesin, ganti ban, café, dan lain-lain.

\section{Gaya hidup masyarakat perkotaan}

Gaya hidup masyarakat di perkotaan yang ditandai dengan pergeseran paradigma berpikir. Di mana semua urusan yang dianggap sederhana seperti mencuci mobil, lebih baik diserahkan ke jasa cuci mobil. Masyarakat yang serba sibuk dan tidak memiliki waktu untuk mencuci mobilnya sendiri, maka akan membuka peluang dan memungkinkan bisnis steam mobil untuk terus berkembang. Masyarakat menginginkan kendaraannya bisa ditangani secara cepat dan bersih.

3. Dekat dengan pemukiman dan tempattempat perbelanjaan

Lokasi tempat pencucian mobil yang dekat dengan pemukiman dan tempat-tempat perbelanjaan akan memungkina usaha steam mobil untuk berkembang. Karena masyarakat akan semakin mudah dan tidak memakan waktu. Apalagi lokasi tempat steam mobil berada persis bersebelahan dengan tempat perbelanjaan atau melalui lokasi-lokasi pemukiman sehingga mudah dijangkau. Masyarakat bisa menghemat waktu tanpa harus mencari-cari lagi lokasi tempat pencucian kendaraan.

\section{Faktor Ancaman Eksternal}

1. Munculnya pendatang baru Adanya pendatang baru merupakan ancaman bagi pemain lama. Biasanya suatu bisnis yang sudah sukses akan diikuti pemain-pemain baru pada bidang bisnis yang sama. Umumnya suatu bidang bisnis yang terlihat banyak pelanggannya, maka akan diminati oleh para pelaku usaha. Pendatang-pendatang baru dapat mengancam keberadaan para pemain lama, kendati sudah eksis dan memiliki pelanggan yang banyak.

2. Hanya mempunyai satu pemasok atau supplier

Apabila manajemen hanya mengandalkan satu pemasok atau supplier, maka akan dapat pula menjadi ancaman. Namun bagi Steam Mobil "Top Clean" hal ini belum menjadi ancaman serius, karena faktor pemasok ini tidak sangat signifikan mengancam keberadaan usaha. Namun, tetap tidak bisa diabaikan apabila 
perusahaan kelak ingin terus berkembang dan memperluas usahanya semakin besar.

3. Persaingan harga dan pelayanan yang semakin kompetitif

Harga dan pelayanan juga akan menjadi ancaman bagi perusahaan. Saat ini karena harga yang ditawarkan dan pelayanana yang diberikan masih dianggap pelanggan cukup untuk kebutuhan mereka, maka belum menjadi ancaman yang cukup serius. Namun, apabila suatu saat ada pelaku bisnis yang sama memberikan harga yang lebih murah dengan pelayanan yang lebih baik dibanding dengan yang diberikan oleh manajemen Steam Mobil “Top Clean", maka tidak tertutup kemungkinan para pelanggan Steam Mobil “Top Clean", akan pindah ke pemain yang baru tersebut. Apalagi, pemain yang baru tersebut memberikan pelayanan-pelayanan yang tidak pernah diberikan oleh Steam Mobil “Top Clean”. Seperti pemberian diskon, penyediaan makanan dan minuman, adanya jaringan Wifi, atau promosi-promosi lainnya yang membuat pelanggan akan merasa nyaman dan betah di tempat pencucian mobil yang baru tersebut.

\section{Analisis Matriks IFAS dan EFAS}

Analisis Matriks IFAS dan EFAS akan memberikan gambaran mengenai lingkungan internal dan eksternal perusahaan. Hal ini digunakan untuk mengevaluasi semua faktor- faktor yang ada, baik yang berasal dari dalam sendiri maupun dari luar.

\section{Analisis Matriks IFAS}

Matriks IFE (Internal Factors Evaluation) dipergunakan untuk mengevaluasi faktor-faktor internal perusahaan berkaitan dengan kekuatan dan kelemahan. Berdasarkan analisis terhadap identifikasi faktor internal Steam Mobil "TOP CLEAN", maka diperoleh tiga kekuatan dan tiga kelemahan yang kemudian akan diberikan penilaian dengan memberikan bobot dan rating sebagai berikut :

\begin{tabular}{|c|c|c|c|c|}
\hline \multicolumn{5}{|c|}{ Tabel 1.3. Matriks IFAS } \\
\hline \multirow{2}{*}{ No. } & \multirow{2}{*}{ Faktor Internal } & \multirow{2}{*}{ Bobot } & \multirow{2}{*}{ Rating } & Nilai Tertimbang \\
\hline & & & & $c=a \times b$ \\
\hline \multicolumn{5}{|c|}{ Kekuatan (Strengths) } \\
\hline 1. & Harga yang murah & 0,20 & 4 & 0,80 \\
\hline 2. & $\begin{array}{l}\text { Lokasi strategis, di pinggir jalan } \\
\text { raya utama }\end{array}$ & 0,20 & 4 & 0,80 \\
\hline 3. & Memiliki 15 orang karyawan & 0,18 & 3 & 0,54 \\
\hline \multicolumn{5}{|c|}{ Kelemahan (Weaknesses) } \\
\hline 1. & $\frac{\text { Fasilitas yang dimiliki masih }}{\text { minim }}$ & 0,14 & 3 & 0,42 \\
\hline 2. & $\begin{array}{l}\text { Disiplin karyawan perlu } \\
\text { ditingkatkan }\end{array}$ & 0,13 & 2 & 0,26 \\
\hline 3. & $\begin{array}{l}\text { Promosi yang dilakukan masih } \\
\text { kurang }\end{array}$ & 0,15 & 3 & 0,45 \\
\hline \multicolumn{2}{|r|}{ Total } & 1,00 & & 3,27 \\
\hline
\end{tabular}

Berdasarkan hasil data pada Tabel 1.3. di atas, maka total skor faktor internal adalah 3,27. Angka ini menunjukkan kategori kuat karena berada di atas 2,50. Hal ini menunjukkan bahwa posisi internal strategi pengembangan Steam Mobil "TOP CLEAN" dikatakan kuat. Dengan demikian akan mampu memanfaatkan faktor-faktor kekuatan yang ada untuk dapat mengatasi faktor-faktor kelemahannya.

\section{Analisis Matriks EFAS}

Matriks EFE (External Factors Evaluation) dipergunakan untuk 
mengevaluasi faktor-faktor eksternal perusahaan berkaitan dengan peluang dan ancaman. Berdasarkan analisis terhadap identifikasi faktor eksternal Steam Mobil “TOP CLEAN” maka diperoleh tiga peluang dan tiga ancaman yang kemudian akan diberikan penilaian dengan memberikan bobot dan rating sebagai berikut :

\begin{tabular}{|c|c|c|c|c|}
\hline \multicolumn{5}{|c|}{ Tabel 1.4. Matriks EFAS } \\
\hline \multirow{2}{*}{ No. } & \multirow{2}{*}{ Faktor Eksternal } & \multirow{2}{*}{ Bobot } & \multirow{2}{*}{ Rating } & Nilai Tertimbang \\
\hline & & & & $\mathbf{c}=\mathbf{a} \times \mathbf{b}$ \\
\hline \multicolumn{5}{|c|}{ Peluang (Opportunities) } \\
\hline 1. & $\begin{array}{l}\text { Jumlah pengguna mobil terus } \\
\text { bertambah }\end{array}$ & 0,20 & 4 & 0,80 \\
\hline 2. & Gaya hidup masyarakat perkotaan & 0,18 & 3 & 0,54 \\
\hline 3. & $\begin{array}{l}\text { Dekat dengan pemukiman dan } \\
\text { tempat-tempat perbelanjaan }\end{array}$ & 0,20 & 3 & 0,60 \\
\hline \multicolumn{5}{|c|}{ Ancaman (Threats) } \\
\hline 1. & Munculnya pendatang baru & 0,15 & 3 & 0,45 \\
\hline 2. & $\begin{array}{l}\text { Hanya mempunyai satu pemasok } \\
\text { atau supplier }\end{array}$ & 0,13 & 2 & 0,26 \\
\hline 3. & $\begin{array}{l}\text { Persaingan harga dan pelayanan } \\
\text { yang semakin kompetitif }\end{array}$ & 0,14 & 3 & 0,42 \\
\hline \multicolumn{2}{|r|}{ Total } & 1,00 & & 3,07 \\
\hline
\end{tabular}

\section{Analisis Matriks IE (Internal - Eksternal)}

Adapun Matriks IE didasarkan pada dua dimensi kecil yaitu skor bobot IFAS pada sumbu X dan skor bobot EFAS pada sumbu Y. Skor bobot total yang diperoleh dari divisidivisi tersebut memungkinkan susunan Matriks IE pada tingkat perusahaan.

Oleh karena itu, berdasarkan dari analisis Matriks IFAS terhadap faktor lingkungan internal di mana menghasilkan total skor sebesar 3,27, yaitu berada di atas rata-rata nilai 2,50. Hal ini berarti posisi daripada faktor internal sangat kuat. Dengan demikian perusahaan dapat memanfaatkan faktor kekuatan untuk mengatasi faktor yang kelemahan yang ada di dalam perusahaan.
Sementara itu berdasarkan analisis Matriks EFAS terhadap faktor lingkungan eksternal, di mana menghasilkan total skor sebesar 3,07 yaitu di atas nilai rata-rata. Hal ini menunjukkan bahwa posisi faktor eksternalnya tidak terlalu kuat, sehingga perusahaan dapat memanfaatkan faktor peluang untuk mengatasi ancaman yang mungkin akan muncul terhadap perusahaan.

\section{Pembahasan}

\section{Matriks Internal-Eksternal (IE) Steam Mobil "TOP CLEAN"}

Berdasarkan dari hasil analisis faktor matriks internal dan matriks eksternal, dapat diketahui hasil yang mencerminkan kondisi Steam Mobil "Top Clean". Dari hasil perhitungan tabel IFAS dan EFAS dapat dipaparkan bahwa diperoleh nilai IFAS sebesar 3,27 dan nilai skor untuk hasil EFAS sebesar 3,07. Apabila dikonversikan ke dalam gambar Diagram IE Matriks, maka hasil yang dicapai terletak pada Kuadran III. Posisi ini menunjukkan perusahaan berada pada fase Pertumbuhan dan Stabilitas (Growth and Stability), di mana posisi competitive position yang sangat kuat. Posisi perusahaan dalam bisnis dapat dilihat pada gambar 1 berikut. 


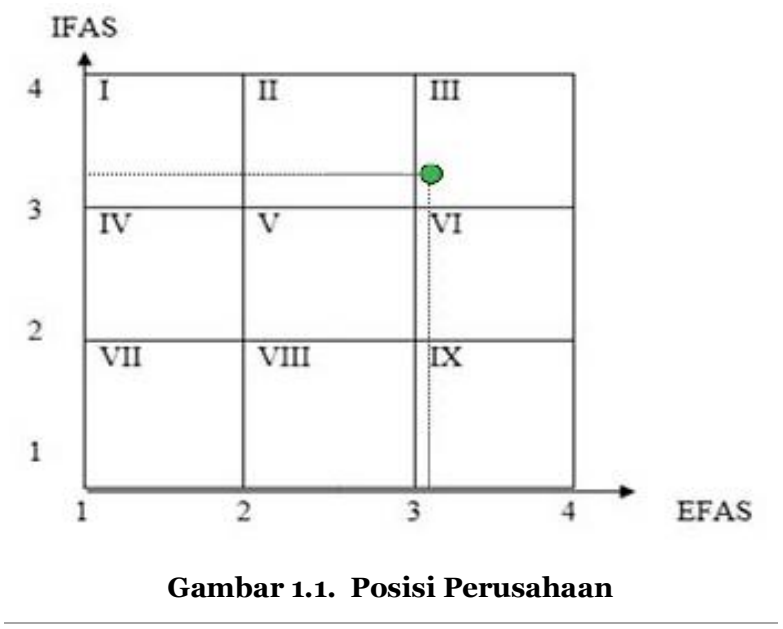

Dari gambar di atas terlihat bahwa perusahaan berada pada Kuadran III. Dengan demikian dapat diketahui bahwa strategi yang sesuai bagi Steam Mobil "Top Clean" terletak pada Kuadran III. Sel ini merupakan kondisi Jaga dan Pelihara yang meliputi Sel III, V, dan VII. Adapun strategi pertumbuhan yang dilakukan adalah dengan konsentrasi melalui integrasi horizontal.

Dalam pengertian lain kondisi perusahaan dapat pula dikatakan berada pada tingkatan growth diversifikasi konsentrik. Kondisi ini bisa disebutkan di mana daya tarik industrinya sangat rendah. Di sini perusahaan berusaha memanfaatkan kekuatannya untuk mengembangkan atau membuat produk baru secara efisien. Sebab dalam kondisi ini perusahaan sudah memiliki kemampuan manufaktur dan pemasaran yang baik.

Perusahaan yang berada pada Sel III, V, dan VII berusaha menjaga dan memelihara kondisi yang sudah diperoleh. Hal-hal yang perlu dilakukan adalah penetrasi pasar dan pengembangan produk. Jaga dan Pelihara (Hold and Maintain). Pertahankan dan Pelihara $=$ Penetrasi Pasar, Pengembangan Produk.

Fred R. David (2011), mengemukakan bahwa perusahaan yang berada pada tingkatan ini merupakan perusahaan yang mengacu pada kegiatan untuk meningkatkan lagi kualitas kerja. Adapun diversifikasi yang terkait ketika rantai nilai bisnis memiliki kesesuaian strategis dan enam pedoman diversifikasi terkait dapat menjadi sebuah strategi yang efektif seperti :

1. Ketika organisasi berkompetisi di sebuah industri yang tidak mengalami pertumbuhan atau yang pertumbuhannya lambat.

2. Ketika menambah produk yang baru namun terkait akan secara signifikan mendongkrak penjualan produk saat sekarang ini.

3. Ketika produk yang baru namun terkait dapat ditawarkan dengan harga yang sangat bersaing.

4. Ketika produk yang baru namun terkait memiliki tingkat penjualan musiman yang dapat mengimbangi puncak dan jurang penjualan yang ada saat ini di perusahaan.

5. Ketika produk organisasi yang ada saat ini sedang dalam tahap penurunan dari siklus hidup produk. 
6. Ketika organisasi memiliki tim manajemen yang kuat.

Sementara itu, strategi pertumbuhan melalui integrasi horizontal seperti dikemukakan oleh Wheelen \& Hunger (2012), dari sisi internal hendaknya segmen pasar diperluas menjadi lebih besar. Sedangkan dari sisi eksternal perusahaan dapat melakukan akuisisi atau joint venture dengan perusahaan pada industri yang sama, dengan didukung oleh strategi dari Analisis SWOT .

Adapun solusi yang dapat dilakukan perusahaan ketika berada pada Kuadran III, yang didukung oleh strategi dari Analisis SWOT adalah :

1. Peningkatan segmen pasar dengan memperluas daerah pemasaran.

2. Melakukan kerja sama dengan perusahaan sejenis.

3. Fokus pada sumber daya manusia perusahaan.

4. Peningkatan yang berkelanjutan.

\section{SIMPULAN}

Berdasarkan hasil penelitian dan pembahasan yang sudah dilakukan, dapat disimpulkan bahwa sesuai dengan hasil evaluasi dan kelayakan bisnis Steam Mobil “TOP CLEAN", apabila ditinjau dari aspek operasional, maka bisnis Steam Mobil "TOP CLEAN", dapat dikatakan layak.

Sesuai dengan hasil penelitian, dari sisi insternal kekuatan Steam Mobil "TOP CLEAN" lebih besar dibandingkan dengan kelemahannya. Kemudian dari sisi eksternal peluang lebih besar dibandingkan dengan ancaman. Sehingga strrategi yang sesuai adalah strategi S-O, yakni menggunakan strategi yang memanfaatkan peluang yang ada dengan mendayagunakan kekuatan yang dimiliki.

Apabila dilihat dari hasil perhitungan IFAS dan EFAS yaitu 3,27 dan 3,07, maka perusahaan berada pada Kuadran III, yaitu strategi pertumbuhan dengan konsentrasi melalui integrasi horizontal. Oleh karena itu, jika kondisinya seperti ini, maka yang bisa dilakukan adalah dengan cara perluasan segmen pasar, kerja sama dengan perusahaan yang sejenis. Selanjutnya fokus pada pengembangan sumber daya manusia dan peningkatan yang berkelanjutan.

Sesuai Matriks SWOT posisi Steam Mobil "TOP CLEAN" menunjukkan growth diversifikasi konsentrik di mana posisi ini merupakan kondisi competitive position yang angat kuat, namun nilai industrinya sangat rendah. Manajemen harus berusaha memanfaatkan kekuatannya untuk membuat produk baru secara efisien dengan kemampuan manufaktur dan pemasaran yang baik. 
Di sisi lain, manajemen masih perlu berusaha untuk memperbaiki hal-hal yang menyangkut aspek operasional. Adapun yang perlu dibenahi antara lain adalah menyangkut produk, sumber daya manusia, fasilitas, teknologi, dan layout.

\section{DAFTAR PUSTAKA}

Assauri, Sofjan. (2011). "Manajemen Pemasaran". Jakarta: PT RajaGrafindo Persada.

Assauri, Sofjan. (2008). "Manajemen Produksi dan Operasi”. Edisi Keempat. Jakarta: Lembaga Fakultas Ekonomi Universitas Indonesia.

David, Fred R. (2011). “Manajemen Strategis Konsep, Kasus dan Implementasi terjemahan”. Jakarta: PT Gasindo.

Handoko, T Hani. (2011). "Manajemen". Edisi Kedua. Yogyakarta: BPFE Yogyakarta Anggota IKAPI.

Hasibuan. (2016). "Manajemen Sumber Daya Manusia". Jakarta: Penerbit Haji Masagung.

Ishak, Aulia. (2010). "Management Operation”. Yogyakarta: Graha Ilmu.

Kuncoro, Mudrajad. (2014). "Metode Riset untuk Bisnis dan Ekonomi”. Edisi 4. Jakarta: Penerbit Erlangga.

Kotler, Philip \& Keller, K. L. (2009). "Manajemen Pemasaran: Analisis, Perencanaan, Implementasi dan Kontrol" Jilid 1 Edisi 13. Jakarta: Penerbit Erlangga.
Kotler, Philip dan Gary Armstrong. (2009). "Manajemen Pemasaran". Edisi Ketigabelas. Jakarta: Penerbit Erlangga.

Kotler, Philip dan Kevin Lane Keller. (2009). "Manajemen Pemasaran", Jilid 1 Edisi Ketigabelas. Jakarta: Penerbit Erlangga.

Kotler, Philip dan Kevin Lane Keller. (2009). "Manajemen Pemasaran", Jilid 2 Edisi Ketigabelas. Jakarta: Penerbit Erlangga.

Kotler, Philip dan Gary Armstrong. (2012). "Prinsip-prinsip Pemasaran", Jilid 1 Edisi Ketigabelas. Jakarta: Penerbit Erlangga.

Kotler, Philip dan Gary Armstrong. (2012). "Prinsip-prinsip Pemasaran", Jilid 2 Edisi Ketigabelas. Jakarta: Penerbit Erlangga.

Laksana, Fajar. (2013). "Manajemen Pemasaran". Edisi Pertama. Yogyakarta: Graha Ilmu.

Lovelock \& Wright. (2012). "Principle of Services Marketing and Management". Upper Saddle River, New Jersey, USA: Prentice Hall Inc.

Manullang. (2012). "Dasar-Dasar Manajemen". Yogyakarta: Gajah Mada University Press.

Martono, Nanang. (2010). "Metode Penelitian Kuantitatif": Analisis Isi dan Analisis Data Sekunder. Edisi Revisi 
2. Jakarta: Penerbit RajaGrafindo Persada.

Naresh, K. Malhotra. (2010). "Riset Pemasaran Pendekatan Terapan”. Edisi Keempat Jilid 2. Jakarta: PT Indeks.

Pearce, Jhon A. dan Robinson, Richard, B. (2011). "Manajemen Strategi: Formulasi, Implementasi, dan Pengendalian”. Jakarta: Salemba Empat.

Raco, J. R. (2010). "Metode Penelitian Kuantitatif: jenis, karakteristik, dan keunggulannya”. Jakarta: Penerbit Grasindo.

Rangkuti, Freddy. (2009). "Analisis SWOT Teknik Membedah Kasus Bisnis Reorientasi Konsep Perencanaan Strategi Untuk Menghadapi Abad 21”. Jakarta: PT Gramedia.

Rangkuti, F. (2013). "Teknik Membedah Kasus Bisnis Analisis SWOT Cara Perhitungan Bobot, Rating, dan OCAI”. Jakarta: PT Gramedia Pustaka Utama.

Rangkuti, F. (2015). “Analisis SWOT: Teknik Membedah Kasus Bisnis”. Jakarta: Gramedia Pustaka Utama.

Render Berry dan Heizer Jay. (2011). "Management Operation". Jakarta: Boston.

Silalahi, Ulber. (2011). "Asas-Asas Manajemen". Bandung: PT Refika Aditama. Anggota IKAPI.
Sri Wahyudi, Agustinus. (2013). "Manajemen Strategik: pengantar proses berpikir strategic”. Jakarta: Penerbit Binarupa Aksara.

Sugiyono. (2010). "Metode Penelitian Bisnis (Pendekatan Kuantitatif, Kualitatif, dan R\&D)”. Bandung: Alfabeta.

Sugiyono. (2012). "Metode Penelitian Kualitatif-Kuantitatif dan $R \& D ”$. Bandung: Alfabeta.

Sugiyono. (2012). Metode Penelitian Bisnis. Bandung: Penerbit Alfabeta.

Supranto, J. (2012). “Metode Riset”. Cetakan 2. Jakarta: Penerbit Rineke Cipta.

Terry, George R. dan Rue, Leslie W. (2012). “Dasar-dasar Manajemen”. Jakarta: Bumi Aksara.

Wheelen, T. L. dan Hunger, J . D. (2012), "Strategic Management and Business Policy : Toward Global Sustainability". Thirteen Edition, Pearson, United States.

Wijayanto, Dian. (2012). "Pengantar Manajemen”. Jakarta: PT Gramedia Pustaka Utama Anggota IKAPI.

Internet :

Albert Humphrey, Teknik Analisis SWOT, dikutip dari https://id.wikipedia.org/ wiki/Analisis_SWOT, tanggal 27 Juli 2019. 